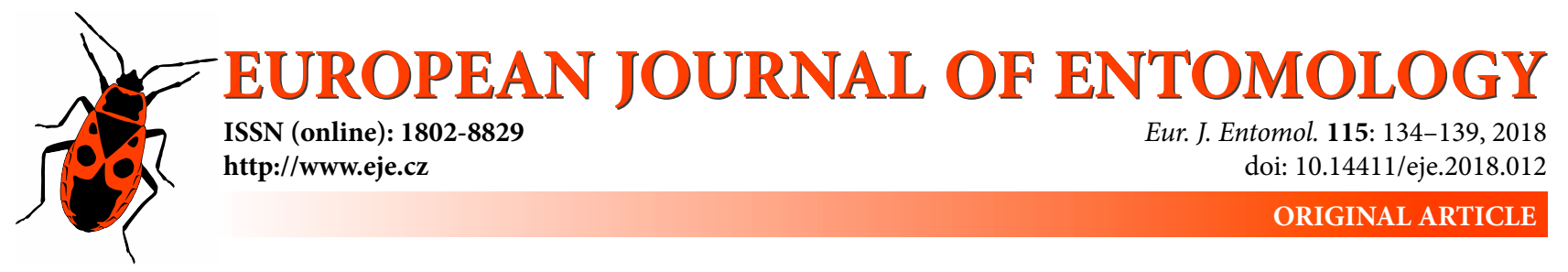

\title{
Structure and function of the male ventral organ in Onychiuroides granulosus (Collembola: Onychiuridae)
}

\author{
Bożena SIMICZYJEW¹, DARIUSZ SKARŻYŃSKI², AdRIAN SMOLIS², RomUALD J. POMORSKI,* \\ and MARTA MAZURKIEWICZ-KANIA ${ }^{1}$ \\ ${ }^{1}$ Institute of Experimental Biology, University of Wrocław, Sienkiewicza 21, 51-335 Wrocław, Poland; \\ e-mails: bozena.simiczyjew@uwr.edu.pl, marta.mazurkiewicz-kania@uwr.edu.pl \\ 2 Institute of Environmental Biology, University of Wrocław, Przybyszewskiego 65, 51-148 Wrocław, Poland; \\ e-mails: dariusz.skarzynski@uwr.edu.pl, adrian.smolis@uwr.edu.pl, onychus@biol.uni.wroc.pl
}

Key words. Collembola, Onychiuridae, Onychiuroides granulosus, springtails, ventral tube, secretory cells, ultrastructure

\begin{abstract}
On the ventral tube of males of Onychiuroides granulosus (Stach, 1934) there is a male ventral organ, which consists of two groups of four setae that are thickened, slightly flattened and bent. All setae of the male ventral organ are inserted in a richly sculptured cuticle. At the base of each seta there are a few large cells (basal cells) that have large irregular nuclei that contain a large amount of heterochromatin. In the cytoplasm of the basal cells there are numerous mitochondria, ribosomes and a rich system of endoplasmic reticulum. The plasma membrane of the basal cells forms richly folded, deep invaginations, filled with a dense material, which also occurs in particular setae and on their surface. The present study indicates that the male ventral organ is secretory and does not confirm its previously suggested sensory function.
\end{abstract}

\section{INTRODUCTION}

Springtails (Collembola) are the largest of the three lineages of Entognatha, with according to Bellinger et al. (2017) about 8600 known species. They have a very wide global distribution, on every continent, including Antarctica. They are usually associated with damp conditions and organic debris and are found outdoors in soil, leaf litter, lichens, rotting wood and other habitats with a high moisture content. As a result, many collembolans remain in close contact with water. The main site of water and salt exchange in springtails is the ventral tube (Eisenbeis, 1982). This structure, which is also called the "collophore", consists of eversible sacs and is on the ventral side of the first abdominal segment. In some species, the vesicles of the ventral tube may extend more than twice the length of the body and be used for self-righting after a jump (Hopkin, 1997). All Collembola are characterized by the presence of a ventral tube. Lubbock (1873) considers the ventral tube to be the most characteristic feature of the group and gave them the name Collembola from kolla (Greek for "glue") and embolon (Greek for "piston"). The ventral tube plays an important role not only in osmoregulation, but can also function as a sticky appendage that enables springtails to adhere to slippery surfaces (Hopkin, 1997). On the ventral tube of males of some Collembola there is ventral organ that is covered by a group of thick and sometimes branching setae, which are clearly distinct from the typical setae covering the body of these insects (Stach, 1934; Pomorski, 1997; Deharveng \& Bedos, 2002). The male ventral organ was first described by Stach (1934) in seven species of the family Onychiuridae. Subsequent investigations revealed the presence of this organ in other springtails but only in species of a few separate phylogenetic lines within the suborder Poduromorpha, namely the families Onychiuridae, Neanuridae, Brachystomellidae and Odontellidae (Hopkin, 1997; Pomorski, 1997; Weiner \& Najt, 2001; Deharveng $\&$ Bedos, 2002; Smolis \& Skarżyński, 2007). The location and morphology of this structure differs depending on the species. The number and spatial arrangement of the setae differ in different species and therefore this structure has become an important diagnostic character in collembolan taxonomy (Babenko \& Kaprus, 2014). However, Snider (1977) states that although the number and arrangement of the setae on the ventral organ does not change during maturation, the appearance of setae changes with the age of a specimen, which can lead to misidentification. Hence, only the ventral organ of adult males is considered to be a reliable taxonomic feature.

The literature includes a wealth of data pertaining to the structure of the male ventral organ, but little is known

\footnotetext{
* Deceased.
} 
about its function. Stach (1934) suggests it has a sensory function, but there is no evidence in support of this view.

The aim of this study was to investigate, using light and electron microscopy, the detail and organization of the male ventral organ of the frequently abundant European species, Onychiuroides granulosus (Stach, 1930) in order to determine its function.

\section{MATERIAL AND METHODS}

\subsection{Material}

Specimens of $O$. granulosus were collected from litter in the forest at Wojnów (Wrocław, Poland) in March-April 2003 and May 2013. They were bred in plastic containers with a gypsum base and added soil, which were kept in a refrigerator $\left(\right.$ at $\left.10^{\circ} \mathrm{C}\right)$.

\subsection{Methods}

\subsubsection{Scanning electron microscope (SEM)}

Whole springtails were fixed in $2 \% \mathrm{OsO}_{4}$ in $0.1 \mathrm{M}$ phosphate buffer for about $1 \mathrm{~h}$. Next, the material was rinsed thoroughly in the same buffer and dehydrated in a series of alcohols (50$100 \%$ ). Subsequently, the specimens were placed into a mixture of absolute alcohol and Peldri II $(1: 1 ; 1 \mathrm{~h})$, placed on a heated table and finally desiccated in Peldri II.

\subsubsection{Light microscope (LM) and transmission electron microscope (TEM)}

Whole males were fixed in $2 \% \mathrm{OsO}_{4}$ in $0.1 \mathrm{M}$ phosphate buffer and then rinsed thoroughly in the same buffer. Subsequently, the material was dehydrated in increasing concentrations of acetone (30-100\%) and embedded in Epon 812. Serial semi thin sections (0.6 $\mu \mathrm{m}$ thickness; $150-200$ sections from every block) were cut with an ultramicrotome (Ultracut E, Reichert). Ultrathin sections $(90 \mathrm{~nm})$ were stained with uranyl acetate and lead citrate and then analyzed using a transmission electron microscope (Zeiss EM 900) in the laboratory of microscopic techniques of the Faculty of Biological Sciences (Wroclaw University).

\section{RESULTS}

In $O$. granulosus the ventral tube is located on the central part of the sternum of the first abdominal segment, immediately behind the third pair of limbs (Fig. 1A, Pomorski, 1998: Fig. 533). This organ is composed of an unpaired basal part and paired distal almost symmetrical halves (Fig. 1C, Pomorski, 1998: Fig. 534). There are cuticular processes on the surfaces of each half (Fig. 1C, D). In males, on the posterior side of each half of the ventral tube there is a ventral organ. The male ventral organ consists of two groups of setae (each containing four setae - Fig. 1B, Pomorski, 1998: Fig. 534). In a sexually mature male the setae on this organ are thick, slightly flattened and characteristically bent, resembling a brush in shape (Fig. 1B, E, Pomorski, 1998: Fig. 535). Typical setae are longer and equally narrow (Fig. 1B, Pomorski, 1998: Fig. 534). Both types of setae are set in a richly sculptured cuticle. The cuticle at the base of a typical seta forms a characteristic ring composed of a dozen or so cuticular granules (Fig. 1B).

On the longitudinal section of the ventral tube, at the base of the ventral organ, there are a few large cells (basal cells) (Fig. 2A, B, C, D). They are located symmetrically in each half, filling almost the whole volume of the ventral tube. The relatively large nuclei of the basal cells are irreg- ular in shape and contain uniformly distributed accumulations of heterochromatin (Fig. 2B, D). There are numerous mitochondria, ribosomes and a few dictyosomes in the cytoplasm of these cells (Fig. 2C, D). In addition, there is an abundant system of endoplasmic reticulum, containing a large number of tubules, canals and vesicles (Fig. 2B). The highest density of endoplasmic reticulum was observed in the apical part of the basal cells (Fig. 2A, B, C). In the cells at the base of a seta, the plasma membrane forms deep invaginations reaching almost to the surface of the nucleus. The membrane of the invagination is richly folded to form a mass of densely packed, thin ducts (channels), regular in size, reaching far into the cell. These channels resemble the elements of the endoplasmic reticulum. The invaginations in the basal cells are filled with a dense material, which produces accumulations of different sizes (Fig. 2A, C). In the vicinity of the plasma membrane and between the invaginations, the dense material forms interconnected granules. In the central part of the invaginations granules fuse to form dense and more uniform aggregates (Fig. 2C, D). Presence of dense material was observed in the entire length of the invaginations, both deep in a cell in the vicinity of the basal cell nucleus and at the base of a seta. The dense material was also detected within the medial part of each seta and in one case material of a similar structure was also found on the outer surface of the setae in the upper zone of the ventral organ (Fig. 1F).

Apart from the typical setae and setae on the outer surfaces of both halves of the ventral tube of the male's ventral organ, there are small single cuticular appendages. These appendages have a slightly clavate shape, rounded top and smooth surface. They are embedded in a smooth un-sculptured cuticle, overlying the inner plane of the ventral tube (Fig. $1 \mathrm{G}, \mathrm{H}$ ). These cuticular appendages are located on the ventral part of the ventral tube. Fragments of the cuticle of these appendages on the ventral tube are lined with transporting epithelial cells.

\section{DISCUSSION}

The male ventral organ within the family Onychiuridae is present in many but not all species (Pomorski, 1997; Pomorski et al., 1998; Kaprus \& Tsalan, 2009; Kaprus et al., 2014). Even within one genus, in some species the male ventral organ is present, while in others it is absent. While there is no male ventral organ in Hymenaphorura strasseri (Stach, 1934) and Hymenaphorura valdegranulata (Stach, 1954), it is present in in Hymenaphorura pseudosibirica (Stach, 1954) (Pomorski, 2000). Kaprus (2008) investigated six species of Onychiurus Gervais, 1841 and did not find the male ventral organ. Similarly, Sun \& Li (2014), studied species of another genus of Onychiuridae: Spinonychiurus Weiner, 1996. In Protaphorura octopunctata (Tullberg, 1876), the male ventral organ exists in the form of two pairs of thick setae, each embedded in an oval cuticular depression on the rear edge of the second abdominal segment (Stach, 1934). In Deuteraphorura silesiaca (Dunger, 1977), the ventral organ is in the same position, but consists of 30 thick and straight setae (Pomorski, 1998). In 

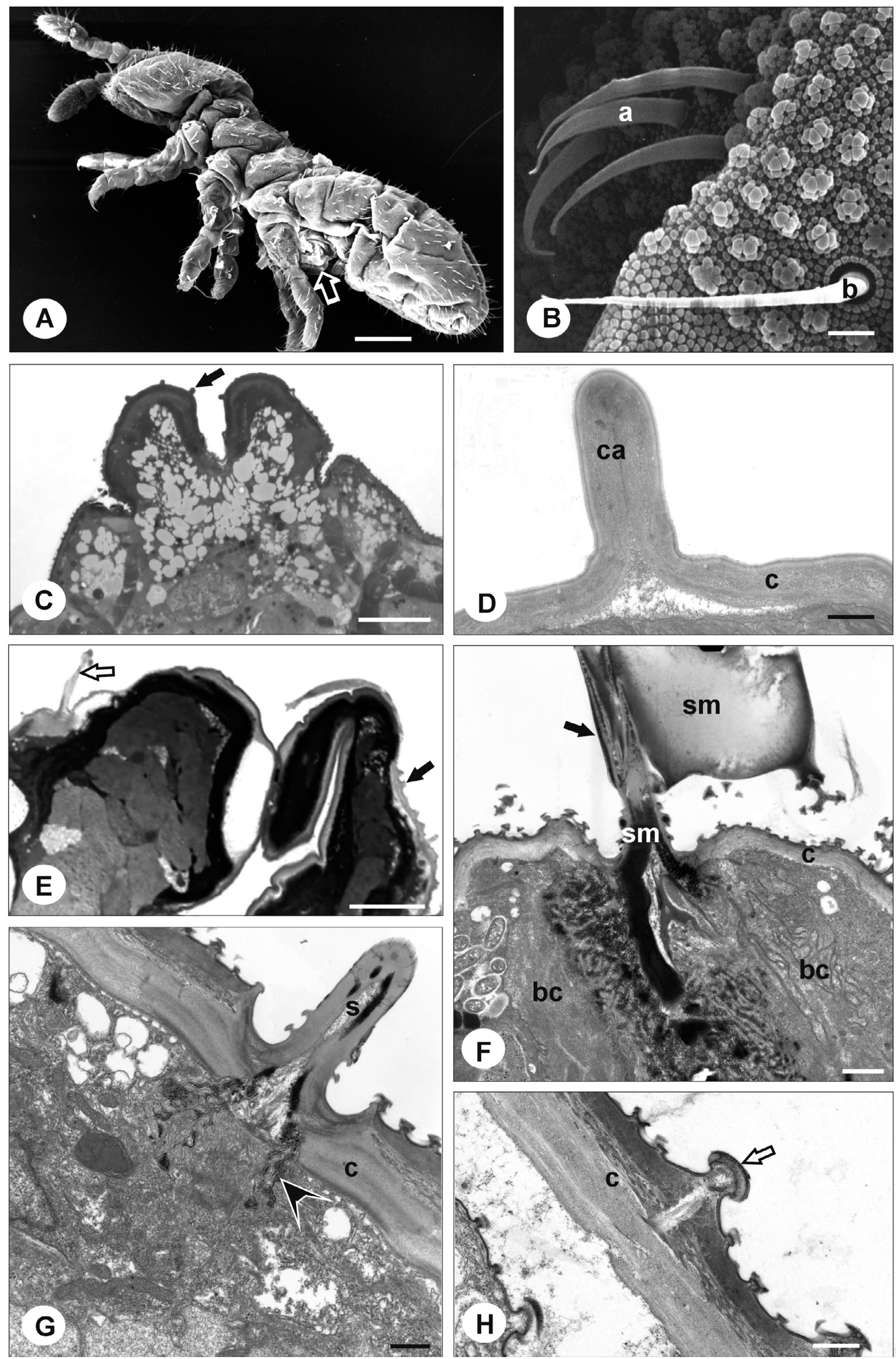

Fig. 1. A-H. Male ventral tube with the male ventral organ of Onychiuroides granulosus. A-general morphology of a male. Arrow indicates the ventral tube on the first segment of the abdomen. SEM. Scale bar: $100 \mu \mathrm{m}$. B - group of thick, slightly curved setae of the male ventral organ (a) in the vicinity of the elongated, narrow, typical setae (b). Bases of both types of setae are in depressions in the sculptured cuticle. SEM. Scale bar: $2 \mu \mathrm{m}$. C - longitudinal section of the ventral tube. Two symmetrical parts are visible. Small cuticular appendages present on the surfaces (arrow). Epon semithin section stained with methylene blue. Scale bar: $50 \mu \mathrm{m}$. D - longitudinal section of a cuticular appendage (ca) protruding from the cuticle (c). TEM. Scale bar: $0.6 \mu \mathrm{m}$. E - semithin section of the apical part of the ventral tube. Empty arrow indicates the thick seta of the male ventral organ; black arrow indicates a cuticular appendage. Scale bar: $50 \mu \mathrm{m}$. F - longitudinal section of basal part of a seta of the male ventral organ (arrow); c - cuticle, sm - secretory material, bc - basal cell. TEM. Scale bar: 1.1 $\mu \mathrm{m}$. G - longitudinal section of typical seta (s) in a depression in the sculptured cuticle (c). At the base of the seta there is a lymph cavity (arrowhead). TEM. Scale bar: $0.6 \mu \mathrm{m}$. H - section of the sculptured cuticle (c) with secondary granules (empty arrow). TEM. Scale bar: $0.6 \mu \mathrm{m}$. 

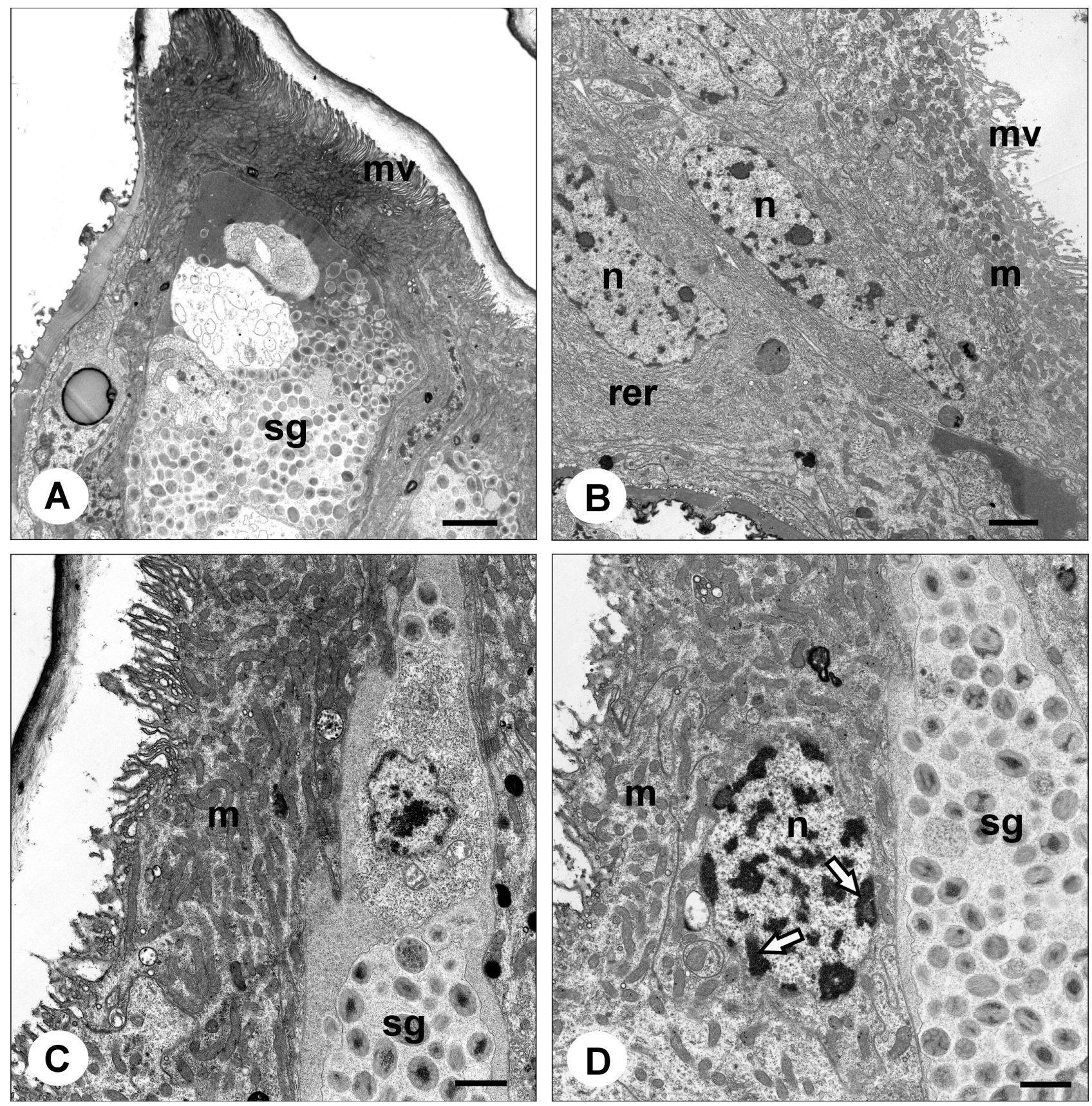

Fig. 2. A-D. Basal cells of the male ventral organ. A - cells at the base of a seta of the ventral organ (basal cells) with numerous secretory granules $(\mathrm{sg})$. The extensive zone of microvilli is visible $(\mathrm{mv})$. TEM. Scale bar: $2.5 \mu \mathrm{m}$. B - basal cells of the male ventral organ. The huge nuclei $(n)$ contain a large amount of heterochromatin. In the cytoplasm there are many mitochondria $(\mathrm{m})$ and an abundance of rough endoplasmic reticulum (rer); mv - microvilli. Scale bar: $1.7 \mu \mathrm{m}$. C - part of a basal cell with numerous mitochondria $(\mathrm{m})$ and secretory granules (sg). TEM. Scale bar: $1.1 \mu \mathrm{m}$. D - basal cells of setae of the male ventral organ. Note large nucleus $(\mathrm{n})$ with accumulations of heterochromatin (arrows). In the cytoplasm there is many mitochondria $(\mathrm{m})$ and secretory granules $(\mathrm{sg})$. TEM. Scale bar: $1.1 \mu \mathrm{m}$.

some species, e.g. Heteraphorura variotuberculata (Stach, 1934), the ventral organ is situated on the third segment of the abdomen, in the middle of the sternum and consists of a group of about fifty thick setae embedded in hollows on the cuticle (Stach, 1934). In some cases the male ventral organ occurs on both the second and third abdominal sterna. An example is Onychiurus ambulans (Linnaeus, 1758), where on the third segment is a single group consisting of many setae, while on the second segment there are two, rather long, thick setae lying close to each other and directed backwards (Stach, 1934). The ventral organ of males of
Onychiurus folsomi consists of a row of four thick setae on the second abdominal segment (Snider, 1977). In Orthonychiurus neocaledonicus (Najt \& Weiner, 1997), the ventral organ is located at the site of the reduced furca and takes the form of four short, thick, pointed setae arranged almost in a line, with each seta in a small cuticular depression (Najt \& Weiner, 1997), whereas in Tantulonychiurus volinensis (Szeptycki, 1964) this organ consists of eight short thick setae forming two rows of four, at the back of the granular area on the fourth abdominal sternum (Pomorski, 1998). In Detriturus jubilarius (Gisin, 1957), the male 
ventral organ is located on the third and fourth abdominal segments: on the third segment it consists of thick setae in sets of $4+4$ in one row in front of the furcal field, while on the fourth segment the same number and arrangement of setae occurs along the edge (Fjellberg, 1998).

Within the Neanuridae, the male ventral organ is present in species of two groups, namely Pseudachorutinae and Neanurinae. In species of these subfamilies this structure occurs on the third, fourth, fifth or sixth abdominal segment. For example, Vitronura mascula (Smolis \& Deharveng, 2006) was named after the extreme development of the male organ, which is composed of more than 20 very thick setae located along the ventral midline from the third to the sixth abdominal segment. In turn, in Vietnura caerulea Deharveng \& Bedos, 2000, the male organ consists of 4-5 short and very thick setae arranged almost in a row on the ventral surface of the fourth abdominal segment (Deharveng \& Bedos, 2002), whereas in Ectonura sensillata Deharveng \& Bedos, 2002, the male ventral organ extends along the fourth, fifth and sixth segment of the abdomen. In Brachystomella villalobosi (Cassagnau \& Rapoport, 1962), (Brachystomellidae), this structure occurs on the fifth segment (Weiner \& Najt, 2001). In the family Odontellidae, the ventral organ is located on the sixth abdominal sternum (Deharveng \& Izarra, 1979).

Stach (1934) describes the male ventral organ in several species of Onychiuridae, including those included in the present study, but only at the morphological level. This author describes the setae of the male ventral organ based on the then contemporary knowledge (most setae have a sensory role) and suggests they have a sensory function. The results presented here do not confirm this hypothesis. The investigation conducted at the ultrastructural level did not reveal the presence of nerve cells within the male ventral organ, which does not support the theory of a sensory function. Morphological (LM) and ultrastructural (TEM) analyses of the male ventral organ in $O$. granulosus indicate a secretory rather than a sensory function. A secretory function is supported by the presence, at the base of the setae of the male ventral organ, of large cells, with an ultrastructure suggesting a synthetic and secretory activity. They have large nuclei with visible accumulations of heterochromatin, which indicates a high level of polyploidy. Enlargement of both the volume of the nucleus and size of the basal cells may be associated with polyploidization, which is a characteristic feature of synthetically active cells (Nagl, 1978). Ultrastructural observations revealed an abundant system of endoplasmic reticulum, numerous mitochondria and ribosomes within the basal cells. The above-mentioned organelles are engaged in cellular synthesis and secretion (Lodish \& Berk, 2008). The apical plasma membrane of the basal cells has characteristic invaginations that extend into the interior of the cells, nearly to the perinuclear surroundings. Inside the invaginations, the spaces between ducts, the area under the setae, and, partly, the interior of the setae are filled with dense material. This material forms smaller or larger aggregates, which are probably a result of the fusion of granules that are present in the basal cells. Material of a similar structure was also observed on the surface of the setae of the ventral organ. What kind of secretion could it be? One hypothesis is that the male ventral organ secretes pheromones, which help females find spermatophores deposited in the soil. It is well known that hexapods communicate with a "chemical tongue" using pheromones produced by special glands. Different types of pheromones are produced by hexapods to induce certain behavioural responses: sex pheromones, aggregation pheromones, alarm pheromones, etc. Some pheromones function as attractants, allowing individuals to detect and locate mates, whereas others induce trailfollowing, oviposition or aggregation in other congeners (Reddy \& Guerrero, 2010).

Despite these ultrastructural observations, there is very little is known about the mechanism of secretion. For example, the very small number of some cellular structures involved in the process of secretion in the basal cells of the ventral organ is puzzling. While the endoplasmic reticulum in the form of tubules and vesicles is abundant, the number of dictyosomes is rather small. Perhaps the paucity of these organelles is related to the dynamics of the secretory processes. Pheromones are secreted only when spermatophores are deposited during the relatively short period of reproduction. Therefore, it is difficult to capture the moment of secretion. A detailed explanation of the function of the male ventral organ requires further research using cytochemical methods.

ACKNOWLEDGEMENTS. The authors would like to express their gratitude to S. Nowak and K. Pajer for their skilled technical assistance. This work was supported by the research grant 1068/S/IBE/16.

\section{REFERENCES}

Babenko A.B. \& Kaprus' I.J. 2014: Species of the genus Protaphorura (Collembola: Onychiuridae) described on material of Yu.I. Chernov from western Taimyr. - Entomol. Rev. 94: 581-601.

Bellinger P.F., Christiansen K.A. \& Janssens F. (1996-2017): Checklist of the Collembola of the world. URL: http://www. collembola.org (last accessed 16 May 2017).

Deharveng L. \& Bedos A. 2002: Nouveaux Ectonura de Nouvelle-Calédonie (Collemboles: Neanuridae). Systématique et endémisme en Nouvelle-Calédonie. - Mém. Mus. Natl. Hist. Nat. 187: 91-102.

Deharveng L. \& Izarra D.C. 1979: Quatre nouvelles espèces francaises du genre Odontella (Collemboles). - Trav. Lab. Ecobiol. Arthr. Edoph. 1: 1-7.

EISENBEIS G. 1982: Physiological absorption of liquid water by Collembola: Absorption by the ventral tube at different salinities. - J. Insect Physiol. 28: 11-20.

Fjellberg A. 1998: The Collembola of Fennoscandia and Denmark. Part I: Poduromorpha. - Fauna Entomol. Scand. 35: $184 \mathrm{pp}$.

HopkIN S.P. 1997: The Biology of the Collembola (Springtails): The Most Abundant Insects in the World. Oxford University Press, London, 330 pp.

KAPRUS' I.J. 2008: Revision of the palearctic Onychiurus species of obsiones group (Collembola: Onychiuridae ). - Invertebr. Zool. 5: 53-64. 
Kaprus' I.J. \& Tsalan J.V. 2009: New Collembola species from the floodplain forests of the Transcarpathian Lowland (Ukraine). - Vestn. Zool. 43: 27-32.

Kaprus' I.J., PASNIK G. \& Weiner W.M. 2014: "Sexually armed" species of the genus Protaphorura (Collembola: Onychiuridae). — Fla Entomol. 97: 465-476.

Lodish H., Berk A., Kaiser C.A., Krieger M., Scott M., Bretscher A., Ploegh H. \& Matsudaira P. 2007: Molecular Cell Biology. W.H. Freeman, New York, 973 pp.

LubBock J. 1873: Monograph of the Collembola and Thysanura. Ray Society, London, 276 pp.

Nagl W. 1978: Endopolyploidy and Polyteny in Differentiation and Evolution. Elsevier/North-Holland, Amsterdam, 283 pp.

NAJT J. \& Weiner M. 1997: Collembola Poduromorpha de Nouvelle-Calédonie. In Najt J. \& Matile L. (eds): Zoologia Neocaledonica 4. Muséum national d'Histoire naturelle, Paris, pp. 9-44.

POMORSKI R.J. 1997: Redescription of Onychiurus rectospinatus (Collembola: Onychiuridae). — Eur. J. Entomol. 94: 121-125.

Pomorski R.J. 1998: Onychiurinae of Poland (Collembola: Onychiuridae). - Genus (Suppl.) 9: $201 \mathrm{pp}$.

Pomorski R.J. 2000: New data on European Hymenaphorura (Bagnall, 1948) (Collembola: Onychiuridae). - Genus 11: 511-520.
Pomorski R., SKARŻYŃSKi D. \& Kaprus’ I. 1998: New Onychiurinae from Crimea (Collembola: Onychiuridae). — Genus 9: 253-263.

Reddy G.V.P. \& Guerrero A. 2010: New pheromones and insect control strategies. - Vitamins Hormones 83: 493-519.

Smolis A. \& Deharveng L. 2006: Vitronura mascula, a new species of Neanurinae (Collembola: Neanuridae) from northern Vietnam, with a key to the species of the genus. - Rev. Suisse Zool. 113: 263-268.

Smolis A. \& SKarżYnski D. 2007: A new species of Pseudachorutella Stach, 1949 (Collembola: Neanuridae) from Poland. Bonn. Zool. Beitr. 55: 73-77.

SNIDER R.J. 1977: Development of instar chaetotaxy of Onychiurus (Onychiurus) folsomi. - Trans. Am. Microsc. Soc. 96: 355-362.

STACH J. 1934: Die in den Höhlen Europas vorkommenden Arten der Gattung Onychiurus Gervais. - Ann. Mus. Zool. Polon. 10: 111-222, pls 26-63.

Sun X. \& Li Y. 2014: New Chinese record of the genus Spinonychiurus (Collembola, Onychiuridae), with the description of a new species. - Zookeys 26: 19-26.

WeIner M. \& NAJT J. 2001: Species of Brachystomella (Collembola: Brachystomellidae) from the Neotropical region. - Eur. J. Entomol. 98: 387-413.

Received February 2, 2018; revised and accepted March 5, 2018 Published online April 6, 2018 